\title{
UMA ABORDAGEM PRÁTICA DO PLANEJAMENTO ESTRATÉGICO GOVERNAMENTAL NA GESTÃO DA ESCOLA MUNICIPAL DE ENSINO FUNDAMENTAL OVIEDO TEIXEIRA: O PROGRAMA DE DESENVOLVIMENTO DA ESCOLA
}

\author{
ARTIGO ORIGINAL \\ SILVA, Roberto Carlos da ${ }^{1}$ \\ SANTOS, Ricardo Jesus dos ${ }^{2}$
}

SILVA, Roberto Carlos da. SANTOS, Ricardo Jesus dos. Uma abordagem prática do planejamento estratégico governamental na gestão da escola municipal de ensino fundamental Oviedo Teixeira: 0 programa de desenvolvimento da escola. Revista Científica Multidisciplinar Núcleo do Conhecimento. Ano 05, Ed. 09, Vol. 09, pp. 82-114. Setembro de 2020. ISSN: 2448-0959, Link de acesso: https://www.nucleodoconhecimento.com.br/educacao/abordagem-pratica

\section{RESUMO}

O presente trabalho pretende analisar a prática de planejamento estratégico na escola municipal de ensino fundamental Oviedo Teixeira, na cidade de Aracaju, Estado de Sergipe. Para tanto, descreveu-se o modelo de planejamento estratégico à luz do Programa de Desenvolvimento da Escola implementado nesta unidade de ensino, em parceria com o Ministério da Educação. Buscou-se também relacionar o modelo acadêmico de planejamento estratégico governamental com a metodologia aplicada

1 Mestre em Educação (2004) pela Universidade Federal de Sergipe - UFS; Especialista em Novas Tecnologias e Desenvolvimento Regional ((2000) pela UFS; Licenciado em Pedagogia (1990) pela UFS; e Licenciado em Matemática (2014) pela Faculdade de Ciências da Bahia - FACIBA.

${ }^{2}$ Especialista em Direitos Infanto-Juvenis, pela UFS/SE, Licenciado em História pela Faculdade de Ciências da Bahia. 
nesta escola. Por fim, verificou-se como foi a implementação do programa de desenvolvimento da escola nesta organização. Nesta perspectiva elegeu-se como objeto de estudo "O planejamento estratégico governamental na Escola Municipal de ensino fundamental Oviedo Teixeira: o programa de desenvolvimento da escola". A pesquisa realizada no trabalho foi de natureza qualitativa exploratória, utilizando-se do método de estudo de caso. O Programa PDE - Escola trabalhado na unidade de ensino alinha-se ao planejamento estratégico governamental estudado na academia. Entretanto, a trajetória do seu desenvolvimento foi marcada por limitações e desafios que refletiram nos resultados, não logrando o êxito esperado, mas de certa forma, contribuindo com a melhoria da organização do coletivo da escola e da sua cultura de participação.

Palavras-chave: Planejamento Estratégico, Gestão Pública, escola, qualidade de serviços.

\section{INTRODUÇÃO}

No contexto de diversas transformações de ordem política, econômica, social e cultural que vem ocorrendo nestas últimas décadas, em especial na sociedade brasileira, e tendo em vista as mutações do capitalismo, o incremento de novas tecnologias da comunicação e da informação e a reforma do Estado (tendência ao modelo gerencial), emerge um mercado que aponta para um cenário altamente volátil, competitivo e com bastante exigência, desencadeando busca de qualidade de produtos e serviços que são ofertados, tanto na esfera pública quanto na privada, dessa forma, afetando também a escola enquanto instituição social e suas práticas pedagógicas e administrativas.

Assim, para qualquer organização, pública ou privada, neste contexto, é imprescindível saber gerir tais mudanças, apresentando resultados convincentes e melhorando as suas práticas de gestão, como também se preparando para as possíveis mudanças em uma visão de futuro. Neste sentido, as organizações recorrem a metodologias de administração e/ou gestão que subsidiem a sua prática cotidiana, tornando-as fortes e sobreviventes aos desafios que são colocados 
constantemente. Dentre estas metodologias, o planejamento estratégico aparece como uma das possíveis soluções para os problemas que se colocam como obstáculos ao emprego de recursos disponíveis, desenvolvimento de atividades e apresentação de resultados satisfatórios, sobretudo no âmbito público.

Para Oliveira (2015),

A partir de meados dos anos de 1990, é crescente o número de organizações públicas que vem refletindo sua forma de gestão, impulsionadas por políticas públicas com foco no modelo gerencial, aderindo a metodologia de gestão estratégica como forma de melhorar seus processos e sobretudo alinhá-los com as políticas vigentes de gestão participativa e societária.

A melhoria da gestão destas entidades é de grande importância para a sociedade, já que a atuação da maioria destas instituições que prestam serviços está relacionada à oferta de produtos e serviços de cunho social. Além disso, a gestão estratégica é uma forma de redimensionamento dos serviços e atendimentos que poderá melhorar a sua qualidade e atendimento.

Diante destas perspectivas e enquanto protagonista educacional surgem algumas indagações: Seria o Planejamento Estratégico uma metodologia capaz de mudar a dinâmica das organizações públicas na busca da melhoria dos serviços? É possível planejar estrategicamente na área educacional? Considerando o Projeto de Desenvolvimento da Escola (PDE - Escola) da EMEF Oviedo Teixeira como um planejamento estratégico, como ocorreu sua efetivação? Quais problemas, limites e desafios encontrados pelos atores sociais nesta prática de planejamento?

$\mathrm{Na}$ busca de respostas para tais questões buscou-se refletir sobre a Gestão Estratégica em uma perspectiva de análise de práticas efetuadas no âmbito de instituições públicas, mais especificamente, a metodologia PDE - Escola aplicada em uma escola pública municipal: a EMEF "Oviedo Teixeira, na cidade de Aracaju SE.

Estudar a temática no âmbito de uma escola pública é de grande importância para a sociedade pois, apesar de o planejamento estratégico ser um tema amplamente discutido, ainda não se tem muitos exemplos de elaboração do mesmo no âmbito 
governamental, considerando que esse conceito teve grande desenvolvimento principalmente nas empresas privadas, enquanto que no setor público já houve discussões acadêmicas dissociadas do campo prático de instituições públicas.

Assim, torna-se relevante o presente estudo na medida em que buscará refletir sobre esse conceito aplicado na prática de uma instituição pública, extrapolando assim os limites da elaboração teórico acadêmica, que é a experiência da metodologia PDE Escola aplicado na Escola Municipal Oviedo Teixeira do sistema de ensino de Aracaju - SE.

O estudo possibilita uma análise da prática de Planejamento Estratégico, verificando os problemas e desafios encontrados pela equipe de gestão que o desenvolve, sendo paralelamente comparado com a teoria acadêmica, formando assim um arcabouço teórico que servirá como fonte de pesquisa, de estudos e/ou ponto de partida para outros estudos de pesquisadores, gestores e acadêmicos interessados na temática visando conhecer mais as práticas de gestão pública, daí a sua relevante contribuição, tanto no meio acadêmico quanto na sociedade de forma geral.

Além disso, é mais um ensaio sobre o planejamento no setor público, tema de grande relevância sociopolítico, tendo em vista a grande necessidade de conhecimento por parte dos gestores públicos para o desenvolvimento de políticas de melhoria dos serviços prestados. Pois, conforme Ossorio (2002, p. 18), o planejamento é uma ferramenta que proporciona a organização da complexidade das relações na sociedade e nas organizações, contribuindo para a criatividade, tornando-se um sistema eficaz na tomada de decisão de modo consciente e reflexivo.

Assim, o planejamento se torna um meio essencial a gestão pública, pois através de sua efetivação na prática pode se agir de forma consciente e produtiva no gerenciamento do patrimônio público. Entretanto, na tradição brasileira, faz se muito planejamento com base nos princípios do Planejamento Normativo Tradicional (PNT), que foca as ações tendo em vista a política econômica, sobrepondo questões mais relevantes como as sociais e políticas. Neste trabalho, busca-se focar o Planejamento Estratégico Situacional (PES) que, de outro modo, enfatiza a importância da 
participação de atores sociais na construção de um planejamento com foco em problemas situacionais de cunho político e social.

Diante do exposto, busca-se esclarecer o problema de pesquisa que consiste em dizer de maneira explícita, clara, compreensível e operacional, qual a dificuldade com a qual nos defrontamos e que pretendemos resolver. Dessa forma, elegeu-se como problema para a presente pesquisa as seguintes indagações: Como é praticado o planejamento estratégico, através programa PDE - Escola, na EMEF Oviedo Teixeira?

Para tanto objetivou-se com este trabalho, em termos gerais, analisar a prática de Planejamento Estratégico na Escola Municipal de Ensino Fundamental "Oviedo Teixeira". E em termos específicos, buscou-se descrever o modelo de planejamento estratégico à Luz do PDE - Escola desenvolvidos na escola foco do objeto de estudo, como também relacionar o modelo acadêmico de Planejamento Estratégico governamental com a metodologia aplicada nesta instituição e ainda verificar a implementação do PDE - Escola enquanto prática de Planejamento Estratégico na EMEF Oviedo Teixeira.

Entretanto, para clarear o objeto de estudo discute-se algumas conceituações que são imprescindíveis para sua compreensão. Assim, aborda-se a seguir a questão do que é planejamento.

\section{PLANEJAMENTO: CONCEITUAÇÃO E DIMENSÃO}

Definir o termo planejamento é complexo em virtude de sua dimensão, amplo e abrangente, embora alguns autores tenham refletido sobre a sua conceituação. Para Gandin (2003), no planejamento deve se ter em vista a ação, pois a elaboração é apenas um dos aspectos do processo, havendo necessidade da execução e da avaliação.

Segundo Gadin (2003) planejar é transformar a realidade numa direção escolhida, é organizar a própria ação, agindo com racionalidade, num processo de intervenção da 
realidade, com certeza e precisão da própria ação e da ação do grupo de trabalho, realizando o que é essencial e imprescindível para sobreviver.

No entanto, há outras especificações, como reflete Santos (2006): "O planejamento determina antecipadamente, o que se deve fazer, quais objetivos a serem atingidos, quais controles serão adotados e que tipo de gerenciamento será pertinente para alcançar resultados satisfatórios". Já Oliveira (2015) explicita o planejamento como um processo desenvolvido para alcançar uma situação futuramente desejada, de modo mais eficiente, eficaz e efetivo, concentrando melhor esforços e recursos da empresa.

Corroborando com o que fora explicitado, Bethlem (2009) explicita que a palavra planejamento "abrange um âmbito tão extenso de atividades humanas que qualquer definição é insuficiente para conter todo o seu significado". Desta forma, torna-se necessário conhecer os tipos de planejamento, existentes e identificá-los.

Segundo Oliveira (2015), os tipos de planejamento diferenciam-se entre si pelos aspectos seguintes: período de duração, áreas de atuação, e abrangência de cada um. Assim, sendo dividido em três tipos: Tático, operacional e estratégico.

O Planejamento Tático, não engloba toda a organização, e é utilizado para solucionar problemas táticos da organização, que afetam determinadas áreas. Este tipo de planejamento não é realizado pela cúpula da organização, pois de acordo com Oliveira (2015) é o planejamento comandado por gerentes intermediários e visa a utilização dos recursos disponíveis de forma eficiente para atingir os objetivos antecipadamente previstos nas estratégias predeterminadas.

A outra tipologia do planejamento é o nível operacional que compreende um planejamento de curto prazo, cuja finalidade corresponde à execução das ações estabelecidas no planejamento tático. Nesta esfera de planejamento ocorre a formalização das metodologias de implantação e desenvolvimento de resultados especializados a serem alcançados pelas áreas de atividades fins da instituição. Este 
planejamento é normalmente elaborado por níveis organizacionais inferiores, com foco nas atividades cotidianas da empresa (OLIVEIRA, 2015).

Já o Planejamento Estratégico é executado pelos níveis mais altos da hierarquia organizacional e se caracterizando pela definição da metodologia para estabelecer a melhor direção para se seguir. Através deste planejamento analisa-se fatores internos e externos da organização, delineando a visão de futuro, o gerenciamento e alocação dos recursos. E, devido a sua complexidade que a responsabilidade pela sua elaboração fica a cargo da alta administração. Para estes gestores deve estar claro os pontos fortes e fracos da empresa, as ameaças e as oportunidades, e a análise da conjuntura econômica como competências mínimas necessárias para se alcançar os objetivos de longo prazo. Como este refere-se especificamente ao tema principal deste trabalho, o qual serão realizadas as considerações oportunas, é dedicada seção exclusiva do trabalho (OLIVEIRA, 2015).

Dessa forma, o planejamento estratégico é um processo que inicia a partir da visão, que algumas vezes irrealistas quanto ao destino da instituição e submetida a uma avaliação racional e criteriosa das oportunidades (mercados a explorar, recursos a aproveitar) e ameaças (que prejudicarão a instituição em suas oportunidades), considerando a realidade da empresa e de seus concorrentes, com seus pontos fortes, fracos e neutros, tudo isso num horizonte estabelecido pela missão, que deve traduzir a escolha de propósitos, a partir de detalhes dos cenários, respeitando a postura estratégica que possibilita o estabelecimento de micro estratégias e macro políticas que orientarão a formalização de objetivos gerais e funcionais, mais realistas que as expectativas e desejos, com base na formulação de desafios e metas, possibilitando estabelecer políticas e meios estratégicos que potencializem os pontos fortes e oportunidades na busca de melhores resultados e eliminem as ameaças e os pontos fracos, traduzindo-os em projetos, planos de ação que orientem a operacionalização do plano estratégico (OLIVEIRA, 2015).

Assim, o planejamento se torna um processo necessário e contínuo no cotidiano das instituições, tendo em vista alcançar a inovação e diferenciação, na busca de melhores resultados. 
Já tendo sido revelado a tipologia de planejamento, cabe agora explicitar o planejamento mais especificamente no campo educacional, já que o campo de estudo da metodologia de planejamento estratégico analisado neste trabalho refere-se à uma unidade escolar.

\section{O PLANEJAMENTO EDUCACIONAL}

A educação escolar não pode ficar fora deste processo de planejamento, uma vez que seu maior objetivo é a busca da qualidade do ensinar e aprender e o planejamento de ações são fundamentais para que a instituição escolar possa atingir suas pretensões de forma refletida, organizada, monitorada e eficiente.

Desta forma, o planejamento educacional contribui significativamente para a organização e direcionamento dos trabalhos na escola. Reconhece-se que há inúmeros problemas, como a falta de condições físicas, evasão, reprovação, falta de capacitação dos docentes, baixos salários, entre outros.

Assim, o planejamento educacional é o instrumento adequado para superação destes problemas, justamente por antecipar uma realidade futura, contribuindo para que haja a possibilidade de uma intervenção eficaz. Dito isso, vale salientar que o planejamento exige um contínuo processo de conhecimento e interpretação da realidade, que necessita ser reflexivo em razão da dinâmica da sociedade. (LIBÂNEO, 2013)

Assim, o planejamento envolve um processo de análise da realidade escolar onde se busca de forma contínua conhecimentos para agregar as suas condições concretas almejando a soluções para os problemas que afetam seu cotidiano e consequente tomada de decisão.

De forma geral, presume-se que 0 ato de planejar se resume em oferecer soluções satisfatórias aos problemas que aparecem no cotidiano. No entanto, para que um planejamento escolar seja eficaz precisa que a sua elaboração seja realizada de forma coletiva, envolvendo os diversos segmentos da escola: conselho escolar, funcionários, professores, gestores, além de representantes de outras instituições que participam 
da comunidade como igrejas, associações, entre outras, assim, dando-Ihes mais legitimidade e possibilidade de efetivação.

De outro modo, quando o planejamento educacional é construído de forma autoritária, burocrática, se torna mais difícil de ser executado, haja vista que o planejamento escolar está repleto de visão de mundo, de sociedade, que poderá ajudar a transformação ou conservação do que está estabelecido pelo sistema.

Neste sentido, o planejamento educacional é aquele apresenta um desenvolvimento amplo, pois tem capacidade de prever e realizar a estrutura de qualquer funcionamento do sistema educacional. São as autoridades educacionais responsáveis por um planejamento, no âmbito da União (Ministério da Educação MEC, do Conselho Nacional de Educação - $\mathrm{CNE}$ ), e na sequência os Estados e Municípios (Secretarias e Conselhos de Educação), com atribuições na área devem elaborar seus planejamentos educacionais.

Assim, no entendimento de Menegolla e Sant'na (2013) o planejamento educacional deverá observar o atendimento da problemática da educação do nível nacional ao escolar, de modo agir diretamente na realidade, atendendo as demandas de cada unidade escolar e as metas estaduais e nacionais.

Dessa forma, fica evidente que o sistema governamental é responsável pelo planejamento educacional, ligado diretamente ao desenvolvimento socioeconômico do país, estado ou município, que formulam seus planejamentos com objetivos e metas para médio e longo prazo, requerendo para sua execução um diagnóstico claro e objetivo da condição educacional de todo país, estado e município.

Entretanto, na dimensão operacional ocorre o planejamento escolar que se realiza a partir das orientações emanadas do ente estatal a quem a escola está subordinada (União, Estado, Município), que a partir destas diretrizes a escola elabora o seu planejamento escolar com a participação de diversos atores escolares, visando democraticamente e na medida do possível atender as demandas da comunidade. 
Neste sentido, Romão (2013) aponta que deve se pensar em planejar a educação partindo de uma cidadania ativa como um fator essencial para a reflexão da gestão de todas as atividades proporcionadas no ambiente escolar e educacional, enfrentando diretamente todos os problemas desta instituição e do sistema educacional.

Diante da necessidade de planejamento compartilhado entre os entes públicos (União, Estados e Municípios) visando a melhoria do contexto educacional brasileiro, como também os resultados da escola, buscou-se inspiração em metodologias de planejamento participativo e democrático, no sentido de participação ativa dos segmentos sociais, dessa forma, sendo colocado o planejamento estratégico como um viés possível. Assim, com o intuito de conhecer melhor esta abordagem será discutida a seguir.

\section{O PLANEJAMENTO ESTRATÉGICO NA ÓTICA DO PROGRAMA DE DESENVOLVIMENTO DA ESCOLA (PDE-ESCOLA)}

O planejamento estratégico é um processo contínuo que abrange quatro preocupações principais: horizonte de tempo maior (longo prazo); amplitude ou abrangência (administração de cúpula); especificação de metas, objetivos e meios para alcançá-los; e relacionamento da organização como ambiente externo. Para que este planejamento possa se materializar e ter uma formatação do foi pensando estrategicamente é importante que se utilize de uma estrutura sistêmica de procedimento, denominada de planejamento estratégico, (KWASNICKA, 2003, apud ACKFF, 2002, p. 14).

Neste sentido, Dagnino, (2009), diz que o planejamento estratégico é uma atividade administrativa que tem como objetivo direcionar os rumos da instituição e dar sustentabilidade as organizações independentes de sua natureza, pública, privada, filantrópica, sempre almejando mudanças e melhoria nos resultados.

Estes horizontes do planejamento estratégico talvez tenham impulsionado os entes públicos, mais especificamente o Ministério da Educação, através do Fundo Nacional 
de Desenvolvimento da Educação a adotar e disseminar pelos Estados e Municípios a metodologia de PDE - Escola. E, partindo desta perspectiva, materializou em diversas unidades de ensino pública o Plano de Desenvolvimento da Escola (PDE Escola) conforme a concepção abordada e defendida por seus idealizadores: Ministério da Educação (MEC), Banco Mundial (BIRD) e o Fundo de Desenvolvimento da Educação - FNDE (MANUAL DO PDE, 2006).

Segundo o Manual do PDE (BRASIL, 2006), o PDE - Escola propõe o planejamento de ações que almeja por uma escola de qualidade, dentre as quais: racionalizar o funcionamento do sistema educacional, tendo como foco a aprendizagem dos alunos, e para tanto, realizando a qualificação da gestão do sistema, utilizando mecanismos para melhoria dos resultados, monitorando e avaliando.

Dessa forma, o manual "Como elaborar o Plano de Desenvolvimento da Escola", elaborado pelo MEC (BRASIL, 2006) coloca em sua apresentação que a escola, enquanto organização, só terá sucesso se conseguir eficiência, eficácia, efetividade e equidade o que implica planejamento, organização, liderança forte e ações controladas, apontando para a necessidade de uma mudança no modelo de funcionamento das escolas. Portanto, as escolas deverão fazer o planejamento assumindo compromisso diante da comunidade e da própria sociedade, com identidade própria, autonomia, definindo metas, estratégias e planos de ação que produzam resultados plausíveis. Assim as escolas precisam planejar, assumir um compro misso diante, daqueles a quem servem e da sociedade, ter uma identidade, autonomia, bem como definir metas, estratégias e planos de ação que tragam resultados verificáveis.

Dessa forma, o PDE - Escola se coloca como resposta a este novo paradigma, dotando a escola de um poderoso e moderno instrumento de planejamento, já que este possibilita que a escola a realize melhor seu trabalho, assegurando que a equipe trabalhe para atingir os mesmos objetivos, focalizando energia, avaliando e adequando a direção e dando resposta a um ambiente em constante mudança. Para tanto, a elaboração do PDE - Escola deve-se observar obrigatoriamente as etapas descritas no manual. Assim, a metodologia PDE - Escola precisa encaixar-se no 
público alvo do plano: escolas públicas municipais e estaduais, consideradas prioritárias conforme dados do Índice de Desenvolvimento da Educação Básica (IDEB), que estejam abaixo da média nacional, (BRASIL, 2006).

Segundo o manual, o Plano de Desenvolvimento da Escola deve ser coordenado pelo diretor (a) da escola que é a liderança de representação máxima (BRASIL, 2006). No entanto, orienta-se a criação de uma estrutura para maior organização e eficiência na elaboração e implementação. O plano do PDE Escola está descrito neste manual com as etapas, a saber:

A primeira etapa é a preparação, momento em que a escola se organiza para elaborar o PDE - Escola. Neste momento constitui-se o grupo de sistematização, aponta quem irá coordenar o PDE, estuda o manual e esclarece para a comunidade escolar as ações para a elaboração do referido plano, (BRASIL, 2006).

A etapa seguinte é a da análise situacional da escola que compreende o diagnóstico e auto avaliação da escola. Nesta etapa se faz a coleta de dados e a respectiva análise situacional identificando seus problemas, as causas que os geraram, daí tomando as medidas para combatê-los com intuito de melhorar sua qualidade. Esta etapa é indispensável para que a escola possa posteriormente elaborar a visão estratégica e o plano de suporte estratégico, (BRASIL, 2006).

$\mathrm{Na}$ terceira etapa ocorre a definição da visão estratégica e do plano de suporte estratégico. Estes consistem em definir o que vai ser feito e para quem, como será feito (estratégias), quanto (metas quantitativas), com quem (responsáveis), quando, onde, custo e financiamento. A visão estratégica designa o conhecimento que a escola tem de si mesma, sobre seus êxitos, seus fracassos, suas potencialidades, suas limitações, suas certezas e os caminhos que pode e quer percorrer (BRASIL, 2006).

Nesta etapa são elaborados, discutidos e apresentados valores, visão de futuro, missão e objetivos estratégicos. Já o plano de suporte estratégico é constituído por estratégias, metas e planos de ação, que define como os objetivos estratégicos serão efetivados, implicando na consistência, constância e no desejo de avaliação dos 
resultados da escola (BRASIL, 2006), comprometendo a equipe diretiva e toda comunidade escolar para aquilo que pretendem realizar para concretizar a visão estratégica da escola.

As próximas etapas do planejamento estratégico são a execução, o monitoramento e avaliação. Estas etapas serão realizadas após a elaboração do PDE - Escola, começando assim as implantações dos planos de ação. Nesta fase devem ser monitoradas sistematicamente todas as ações para que produzam os resultados esperados e devem ser concebidas estratégias para a elaboração de prestação de contas e divulgação dos resultados" (BRASIL, 2006, p. 171).

Segundo o documento, é de máxima importância que as metas sejam desdobradas em planos de ação, as ações articuladas e as responsabilidades bem definidas, cuja execução seja medida através de indicadores, após desenvolvidas na escola.

Esta Estratégia foi aplicada em diversas unidades de ensino pública de todo Brasil, sendo orientada e custeada pelo Fundo Nacional de Desenvolvimento da Educação. Dentre as unidades de ensino que desenvolveu a metodologia PDE - Escola, a Escola Municipal de Ensino Fundamental Oviedo Teixeira, do município de Aracaju, capital do Estado de Sergipe, será o objeto deste estudo.

\section{A ESCOLA MUNICIPAL DE ENSINO FUNDAMENTAL (EMEF) "OVIEDO TEIXEIRA"}

A Escola Municipal de Ensino Fundamental Oviedo Teixeira está localizada no bairro Olaria, zona leste do município de Aracaju, Estado de Sergipe, tem médio porte, funciona nos turnos matutino com ensino fundamental de $1^{\circ}$ ao $5^{\circ}$ ano, no turno vespertino, com ensino fundamental do $6^{\circ}$ ao $9^{\circ}$ ano e no turno Noturno com Educação de Jovens e Adultos: CICLOS ( $1^{\circ}$ ciclo ( $1^{\circ}$ ao $3^{\circ}$ ano); $2^{\circ}$ ciclo ( $4^{\circ}$ e $5^{\circ}$ ano) e em ETAPAS: $1^{\underline{a}}$ a $4^{a}$ etapas correspondendo do $6^{\circ}$ ao $9^{\circ}$ ano.

A implantação do Plano de Desenvolvimento da Escola (PDE - Escola) na Escola Municipal Oviedo Teixeira, buscou equacionar e viabilizar soluções para os problemas 
desta unidade de ensino, que situada em zona periférica da capital sergipana, apresentava baixos índices educacionais, mensurados e demonstrados através de seus resultados em indicadores educacionais do MEC/INEP (Prova Brasil e o IDEB), naquele momento.

A escola tem autorização para funcionamento emitida pelo Conselho Municipal de Educação de Aracaju, apresentando quatro matrizes curriculares: Ensino Fundamental ( $1^{\circ}$ ao $5^{\circ}$ ano), Ensino Fundamental ( $6^{\circ}$ ao $9^{\circ}$ ano), EJA/CICLOS $\left(1^{\circ}\right.$ ao $5^{\circ}$ ano) e EJA/ETAPAS (6ำ ao $9^{\circ}$ ano). No que se refere ao aparato legal conta ainda com um Regimento Escolar e Projeto Político Pedagógico que regem as relações pedagógicas discentes e docentes da unidade de ensino.

A escola atende a população escolar do bairro Olaria, localizado na zona leste da capital sergipana, constituído a partir de invasão, que com o decorrer dos anos foram sendo legalizadas, sendo um dos bairros mais populosos da capital sergipana, tendo a população sendo constituída, em sua maior parte, por pessoas provenientes de cidades do interior do Estado de Sergipe e de outras cidades de estados vizinhos que migram para a capital em busca de emprego e melhoria da qualidade de vida (DOCUMENTOS ESCOLAR, 2017).

O bairro Olaria conta com serviços de infraestrutura como pavimentação da maioria das ruas, serviço de água, energia elétrica e telefonia. No que diz respeito a estrutura de serviços ofertados pelo município existe dois prédios escolares de médio porte e um posto de saúde. A população conta ainda com um imóvel onde funciona a associação de moradores, que tem sido palco de encontros e reuniões. Além das instituições públicas existentes em sua estrutura, estão localizados no bairro lojas de comércio, mercearias, supermercados, restaurantes e bares. Nas proximidades bairro encontra-se a divisa com o município de Nossa Senhora do Socorro, do qual grande parte da população frequenta o bairro Olaria e usufrui de seus serviços públicos, inclusive do ensino ofertado na escola objeto de estudo.

A população do bairro Olaria, do município de Aracaju - SE é constituída de cerca de $22 \%$ de pessoas que nasceram na localidade e $78 \%$ provenientes de outras 
localidades, cidades do interior de Sergipe e de outras unidades da federação. Há predominância de pessoas pardas (48\%) e negras (32\%), sendo os $20 \%$ restante brancos ou que não declararam a sua própria cor. A população é constituída de uma maioria de jovens, ou seja, cerca de $72 \%$ da população, sendo que apenas $22,5 \%$ desses jovens estão inseridos no mercado de trabalho formal. A maioria encontra-se trabalhando em atividades informais ou estão desempregados. A renda familiar é baixa, em média 1,2 salário mínimo, sendo a maioria assistida por programa de distribuição de renda do governo federal, (IBGE, 2010).

O nível de escolaridade das pessoas é baixo, de acordo com os dados referentes às pessoas acima de 18 anos, constata-se que cerca de 32\% têm ensino fundamental incompleto, $26,4 \%$ concluíram o ensino fundamental, $23 \%$ concluíram o ensino médio e somente $4 \%$ tem curso superior (IBGE, 2010).

A Unidade escolar onde foi desenvolvido o estudo fica localizada na Avenida Santa Gleide, às margens da rodovia Lauro Porto, uma via de acesso e saída da capital sergipana, atualmente com grande fluxo de veículos. Devido ser uma via pública de trânsito intenso de veículos que fazem o tráfego de cidades do interior para a capital, na reforma realizada no prédio da escola mudou o acesso de entrada da escola para uma rua perpendicular à rodovia.

Além da rodovia, termos de infraestrutura no entorno da escola EMEF Oviedo Teixeira apresenta cobertura asfáltica em toda a sua extensão, as ruas estão pavimentadas, existe a oferta de energia elétrica, de água canalizada e coleta de lixo. Já o serviço de esgotamento sanitário é precário, a rede pública de tratamento dos esgotos é ruim, existe um canal descoberto que constantemente transborda, sempre apresentando problemas como vazamentos e contaminação do solo e exalação de mau cheiro nos arredores. Estes problemas já foram objetos de denúncias nos meios de comunicação como rádio e Televisão como também no Ministério Público Estadual, conforme informações prestadas por moradores locais.

A unidade escolar está cercada com muro, grades e câmeras possivelmente porque vem ocorrendo com grande frequência roubos e furtos, tanto contra os atores 
escolares (alunos, professores, pais e funcionários da escola), quanto com o próprio patrimônio da escola. Além destes itens de segurança, a unidade escolar conta com uma equipe permanente da guarda municipal que fazem a segurança local. A figura 3 apresenta estes aspectos de isolamento através das grades de proteção, desde a fachada da escola.

Figura 1 - Fachada da Escola

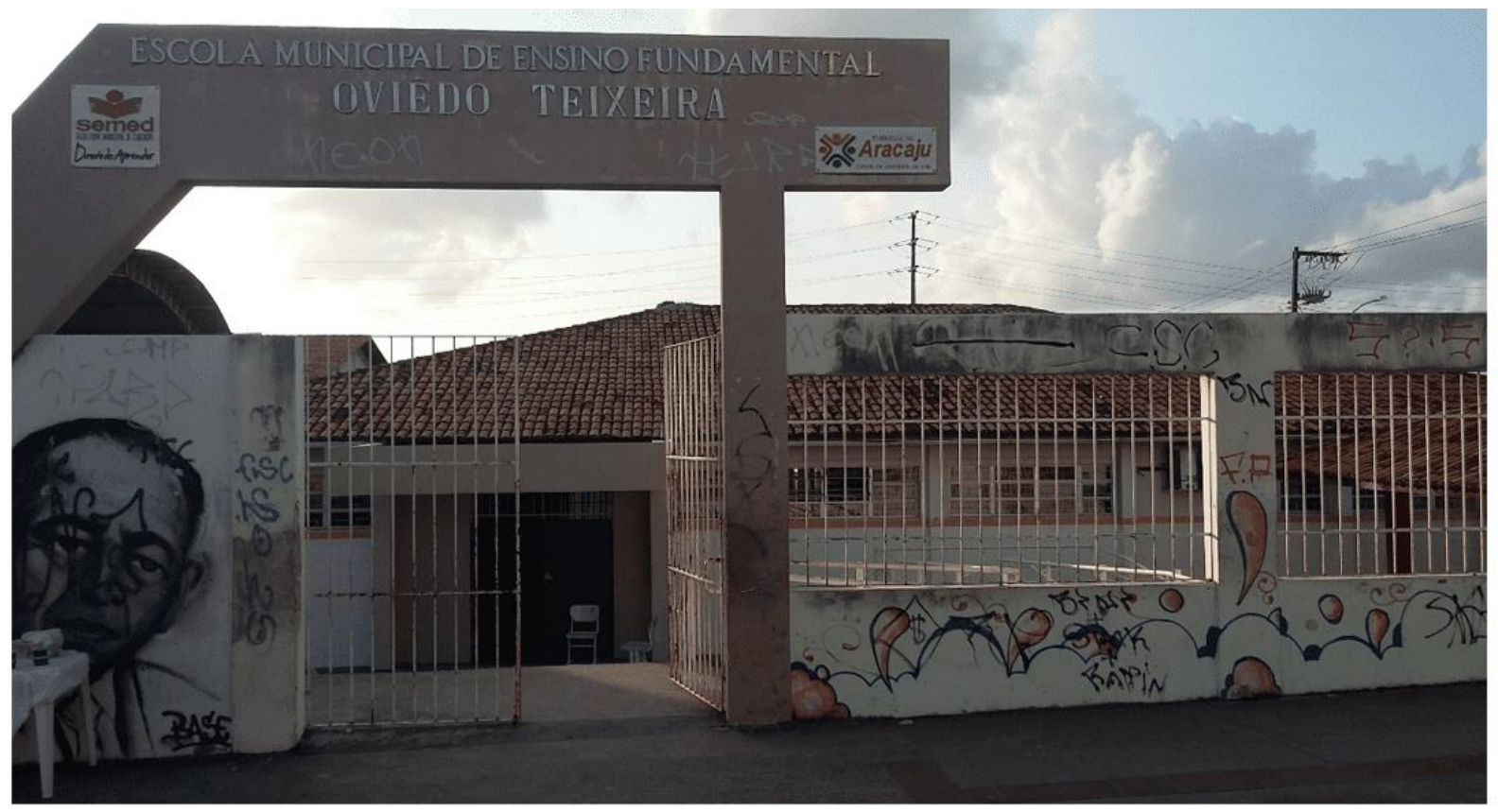

Fonte: Elaborado pelo Autor, 2018.

No que diz respeito a sua estrutura interna apresenta salas de aula com quadro de giz misto (verde, para uso de giz; branco, para uso de pincel atômico). As salas apresentam boa areação, mas algumas têm ventiladores para melhorar a circulação do ar nos dias de muito calor. A iluminação natural é boa, mas todas estão equipadas com lâmpadas fluorescentes para uso quando necessário. $\mathrm{Na}$ infraestrutura elétrica observou-se que não oferece pontos de energia necessários ao uso de tecnologias como por exemplo, computadores. O mobiliário encontra-se em bom estado de conservação. Estes aspectos poderão ser visualizados nas figuras 2 a 5 apresentadas. 
Figura 2 - Interior de sala de aula da E. M. E.F. Oviedo Teixeira

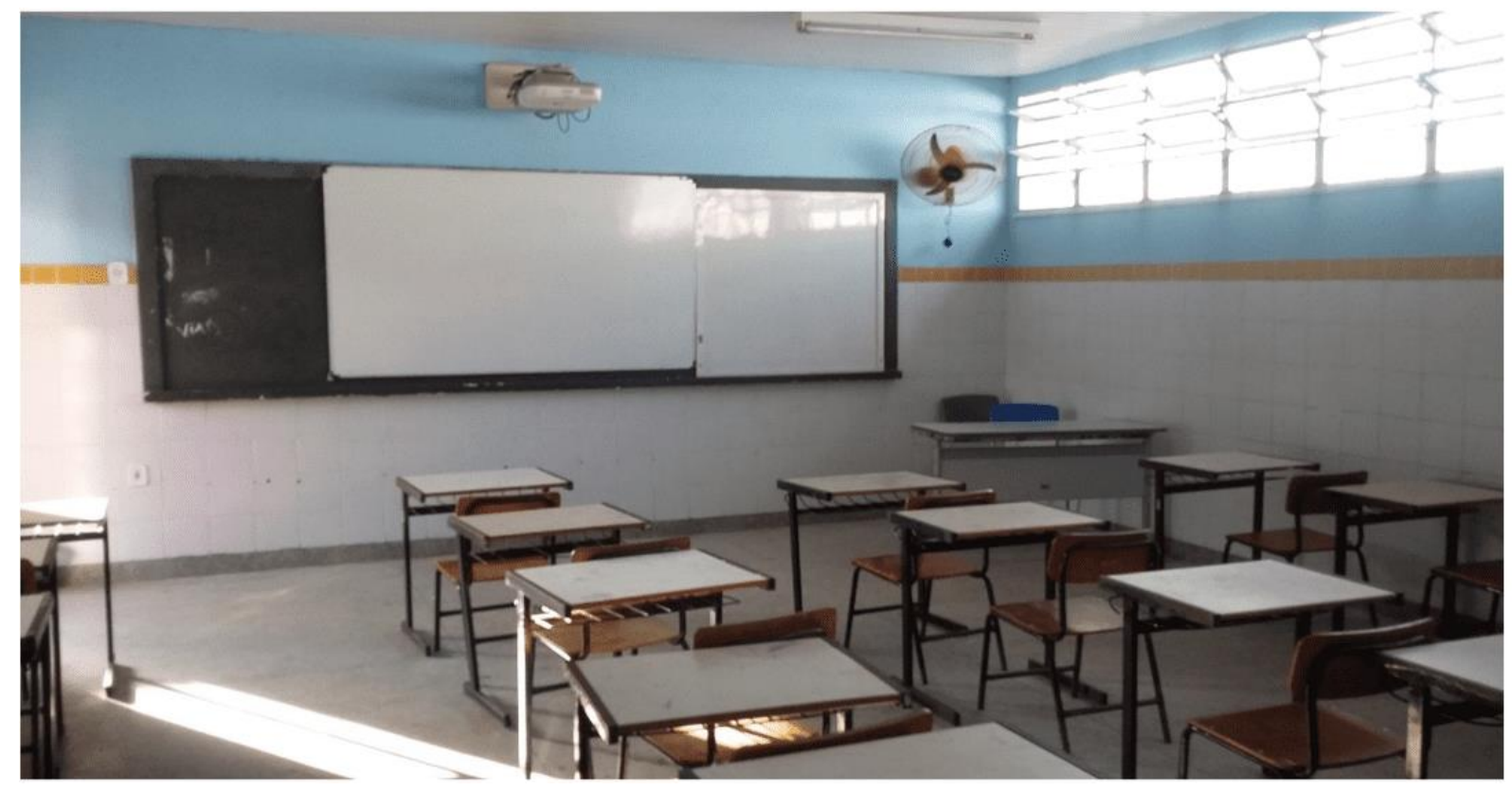

Fonte: Secretaria Escolar, 2018.

$\mathrm{Na}$ escola podemos considerar que têm apenas uma sala de leitura (biblioteca) com estantes onde estão armazenados livros didáticos e livros de literatura infanto-juvenil que servem de apoio didático aos estudantes e professores na elaboração de suas tarefas escolares. Existe um laboratório de informática equipado com computadores ligados à internet que poderão ser utilizados por discentes e docentes para fins didáticos e pesquisas.

Além do laboratório de informática a escola conta ainda com quadra poliesportiva coberta onde são desenvolvidas atividades esportivas, recreativas e pedagógicas pela comunidade escolar.

Em termos de infraestrutura de apoio existe no prédio escolar uma cozinha equipada onde são confeccionados os lanches escolares servidos no refeitório com bancadas em espaço bastante amplo, como também depósito para guarda de alimentos, com prateleiras e frízeres para acondicionamento de materiais perecíveis que serão usados no preparo das refeições. A escola conta ainda com três conjuntos de banheiros distribuídos pelo prédio, com banheiros identificados para uso masculino e 
feminino, além de banheiros adaptados para pessoas com necessidades especiais. $\mathrm{Na}$ entrada do prédio tem um hall coberto que dar acesso a sala de secretaria escolar e também aos blocos de salas de aula.

Figura 3 - Infraestrutura interna da EMEF Oviedo Teixeira- Hall de circulação

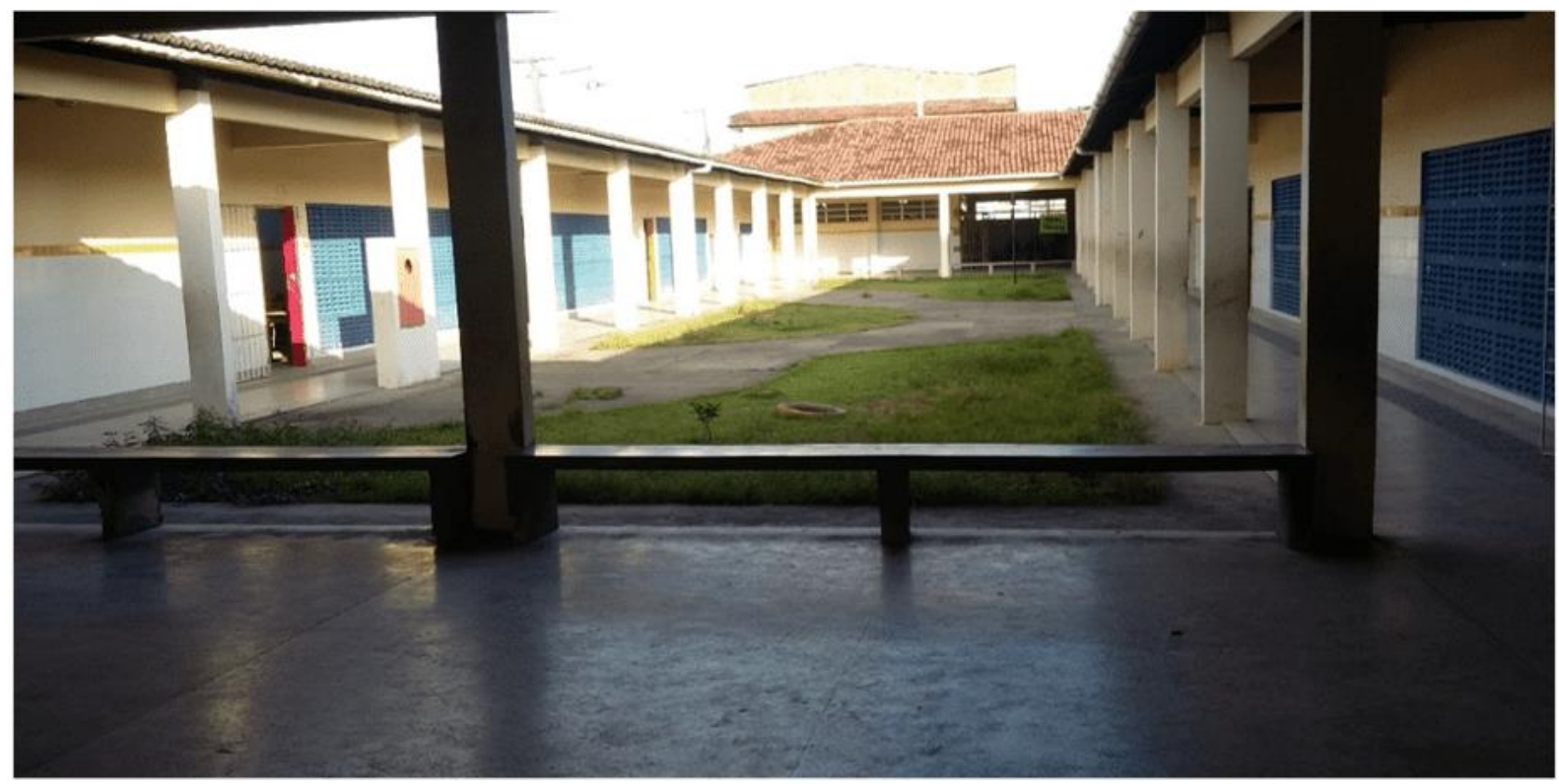

Fonte: Secretaria Escolar, 2018.

Notadamente a escola apresenta boa infraestrutura, com amplos espaços destinados a prática de atividades pedagógicas e de apoio, como também as atividades de gestão do estabelecimento de ensino.

O hall de entrada da escola onde há a recepção das pessoas e se tem acesso a secretaria da escola, como também aos blocos onde estão situadas as salas de aula e demais espaços de realização de atividades internas, tais como refeitório, quadra de esportes, biblioteca, cozinha, sala dos professores.

A gestão da escola é constituída por quatro coordenadores: um Coordenador Geral, dois Coordenadores Pedagógicos e um Coordenador Administrativo, todos auxiliados por uma Secretária escolar e apoiados pelo Conselho Escolar (Órgão Colegiado Consultivo e deliberativo). 
Os recursos materiais gastos na escola são disponibilizados pela secretaria municipal de educação através de verba própria (PROFIM), destinados a compra de materiais de consumo, expediente, limpeza e pequenos reparos no patrimônio.

Os recursos financeiros extraordinários que foram aplicados na unidade escolar foram provenientes do PDE - Escola (Programa de Desenvolvimento da Escola) disponibilizado pelo governo federal através do MEC/FNDE, em dois momentos, anos letivos de 2008 e 2012 visando o desenvolvimento do projeto de plano estratégico pensado pelos atores escolares nestes dois períodos.

\section{METODOLOGIA DA PESQUISA}

A pesquisa realizada para embasar o estudo sobre o planejamento estratégico da EMEF Oviedo Teixeira, sob o viés do PDE - Escola, é de natureza qualitativa e exploratória. O objetivo é familiarizar-se com um assunto é ainda pouco explorado na seara das instituições públicas. Ao final desta pesquisa exploratória, o pesquisador conhece mais sobre aquele assunto, e estar apto a construir hipóteses. Este tipo de pesquisa devido ser muito específica, geralmente se formata num estudo de caso. Como qualquer pesquisa, ela depende também de uma pesquisa bibliográfica sobre a temática abordada.

Para Yin (2005), os questionamentos de estudo são fundamentos lógicos justificáveis para se conduzir um estudo exploratório. Além disso, as questões substituem os objetivos específicos e compõem o roteiro da pesquisa. Diante de tais colocações, foram formuladas as seguintes questões de pesquisa: Como ocorreu o Projeto de Desenvolvimento da Escola (PDE - Escola) da EMEF Oviedo Teixeira? Quais problemas e desafios encontrados pelos atores sociais na prática deste planejamento estratégico? Qual a relação entre o modelo acadêmico de Planejamento Estratégico governamental com a metodologia do PDE - Escola aplicada nesta instituição?

Neste sentido, buscou-se empregar como método da pesquisa o estudo de caso. Segundo Yin (2005) este método é conveniente quando se a pretensão de investigar o como e o porquê de um conjunto de eventos contemporâneos. Ainda, para este 
autor, o estudo de caso é uma investigação empírica que permite o estudo de um fenômeno contemporâneo dentro de seu contexto da vida real.

Os sujeitos da pesquisa são os próprios atores escolares que participaram do processo de gestão do PDE - Escola: Professores (05), Gestores (03), Funcionários (02) e membros do Conselho Escolar (05), destes últimos, pessoas da comunidade (pais de alunos).

Segundo Yin (2005) existem seis fontes de evidências, sendo estas representadas por: documentação, registros em arquivos, entrevistas, observações participantes e artefatos físicos. Para o referido autor, exceto para os estudos que investigam sociedades que dominam a arte da escrita, é provável que as informações documentais sejam relevantes a todos os tópicos do estudo de caso. Nesta perspectiva, os documentos a serem considerados são representados por pesquisas, relatórios, documentos administrativos da unidade de Ensino, tais como: Projeto do PDE - Escola, Atas de constituição do Comitê, Planilhas, Projeto Político Pedagógico, Regimento Escolar, Planos de aula; Observação direta, Artefatos físicos, entrevista.

As categorias analíticas e os elementos de análise alinhados aos objetivos específicos que constituíram a base para o estudo, bem como, o número de questões do roteiro de entrevista utilizadas para atingir cada objetivo específico estão apresentados no Quadro 1 a seguir.

Quadro 1 - Objetivos específicos, categoria de análises e elementos de análise

\begin{tabular}{|c|c|c|c|}
\hline Objetivos Específicos & Categorias de análise & Elementos de análise & Questões \\
\hline $\begin{array}{l}\text { Descrever o modelo } \\
\text { de planejamento } \\
\text { estratégico à Luz do } \\
\text { PDE-Escola } \\
\text { desenvolvidos na } \\
\text { escola foco do } \\
\text { objeto de estudo; }\end{array}$ & $\begin{array}{ll}\text { Modelo } & \text { de } \\
\text { planejamento } & \\
\text { estratégico } & \\
\text { desenvolvido } & \text { no } \\
\text { projeto de } & \text { desenvolvimento da } \\
\text { escola (PDE-Escola) }\end{array}$ & $\begin{array}{l}\text { - Características do } \\
\text { programa do PDE- } \\
\text { Escola }\end{array}$ & 01 \\
\hline
\end{tabular}




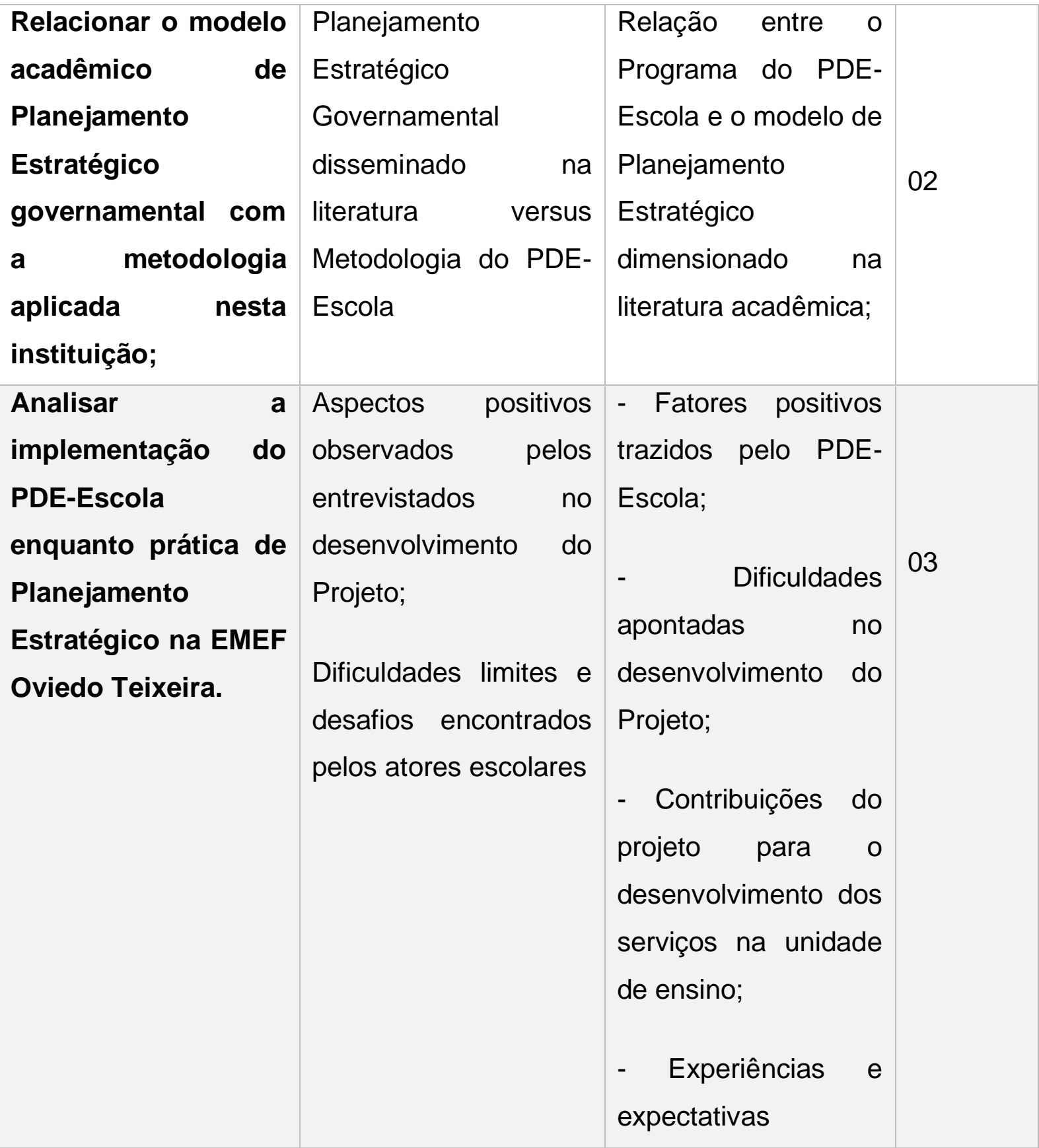

Fonte: Elaborado pelo autor (2018)

O protocolo de estudos conforme Yin (2005) serve para orientar o pesquisador sobre a maneira em que se deve conduzir a análise, além disso, é um instrumento que assegura o máximo de confiabilidade ao estudo de caso. No Quadro 2 é apresentado os elementos que compõem o protocolo de estudo de caso realizado na presente pesquisa. 
Quadro 2 - Protocolo de Estudos

\begin{tabular}{|c|c|}
\hline Questão de Pesquisa & $\begin{array}{l}\text { Como ocorreu o Projeto de Desenvolvimento da } \\
\text { Escola (PDE- Escola) da EMEF Oviedo Teixeira? }\end{array}$ \\
\hline Unidade de Análise & $\begin{array}{l}\text { Escola Municipal de Ensino Fundamental Oviêdo } \\
\text { Teixeira em Aracaju- SE. }\end{array}$ \\
\hline Organização & A Gestão do PDE- Escola da EMEF Oviedo Teixeira \\
\hline de tempo & de 2008 \\
\hline $\begin{array}{l}\text { Fontes de dados e } \\
\text { confiabilidade }\end{array}$ & $\begin{array}{l}\text { Cruzamento entre dados coletados mediante } \\
\text { entrevistas e dados documentais. }\end{array}$ \\
\hline Validade dos dados & $\begin{array}{l}\text { Fonte múltipla de evidência (documentos, entrevista, } \\
\text { observações) }\end{array}$ \\
\hline $\begin{array}{l}\text { Questão do Estudo de } \\
\text { Caso }\end{array}$ & $\begin{array}{l}\text { Como ocorreu a prática de Planejamento Estratégico } \\
\text { na Escola Municipal de Ensino Fundamental "Oviedo } \\
\text { Teixeira"? } \\
\text { Qual a relação entre o modelo acadêmico de } \\
\text { Planejamento Estratégico governamental com a } \\
\text { metodologia do PDE- Escola aplicada nesta } \\
\text { instituição? É possível planejar estrategicamente na } \\
\text { área educacional? } \\
\text { Quais problemas e desafios encontrados pelos } \\
\text { atores sociais nesta prática de planejamento } \\
\text { estratégico? }\end{array}$ \\
\hline $\begin{array}{l}\text { Procedimento de campo } \\
\text { do protocolo } \\
\text { (PREPARAÇÃO) }\end{array}$ & $\begin{array}{l}\text { Elaboração do Roteiro de entrevistas } \\
\text { Contato com os participantes - unidade de análise }\end{array}$ \\
\hline $\begin{array}{l}\text { Procedimento de campo } \\
\text { do protocolo (ação) }\end{array}$ & $\begin{array}{l}\text { Agendamento das entrevistas } \\
\text { Realização das entrevistas } \\
\text { Transcrição das entrevistas }\end{array}$ \\
\hline
\end{tabular}




\section{Relatório do Estudo de Consolidação dos dados} caso

Confronto dos dados com os objetivos da pesquisa

Fonte: Elaborado pelo autor do trabalho (2018).

O agrupamento dos dados apresentados foi relevante como suporte para elaboração do roteiro de entrevista e da análise dos resultados. Assim, torna-se possível validar o estudo, evitando a sua subordinação à subjetividade do pesquisador. Após a coleta dos dados foi realizada a avaliação, análise e triangulação dos dados.

\section{APRESENTAÇÃO, ANÁLISE E DISCUSSÃO DOS RESULTADOS}

Para a análise dos resultados buscou analisar os seguintes elementos: Características do programa do PDE- Escola, Relação entre o Programa do PDE- Escola e o modelo de Planejamento Estratégico dimensionado na literatura acadêmica, Fatores positivos trazidos pelo PDE- Escola; Dificuldades apontadas no desenvolvimento do Projeto, Contribuições do projeto para o desenvolvimento dos serviços na unidade de ensino, Experiências e expectativas. A seguir, apresenta-se as categorias analisadas no trabalho.

Inicialmente buscou-se conhecer como ocorreu o processo de implantação do PDEEscola na unidade de ensino. Ficou evidente, tanto na documentação pesquisada quanto nas respostas dadas à entrevista, que no primeiro momento ocorreu um curso de capacitação para os gestores das Secretarias municipais de educação sobre a metodologia. Este curso foi ministrado por técnicos do Fundo Nacional de Desenvolvimento da Educação - FNDE, na capital sergipana, abrangendo os Técnicos das Secretarias Estadual e Municipais de Educação, visando formação destes na metodologia PDE- Escola, que os tornariam disseminadores nas Unidades escolares.

A partir desta capacitação, as secretarias de educação se organizariam para ofertar a capacitação aos gestores das escolas, trabalhando cada aspecto de como se 
desenvolveria a metodologia PDE- Escola em cada unidade de Ensino. Participou desta capacitação a equipe diretiva (diretor e coordenador).

No que diz respeito a implementação do PDE- Escola na unidade de Ensino EMEF Oviedo Teixeira, buscou-se indagar, com a aplicação de questionários, alguns atores escolares (Coordenador, Professores e membros do Conselho Escolar) para verificar a sua avaliação a respeito do desenvolvimento e resultados do Projeto de Desenvolvimento da Escola (PDE- Escola).

Perguntou-se: Qual a importância do Planejamento da escola na perspectiva do PDEEscola? As respostas dadas foram variadas, desde aquelas de cunho pessimista que disse não ajudar em nada até aquelas que mostrou ter havido benefícios para a escola, como demonstra o depoimento do Gestor Escolar A:

O plano é interessante, além de envolver a comunidade escolar na elaboração do plano, faz uma reflexão sobre os problemas da escola que poderão impactar nos resultados, faz uma análise dos resultados, dos pontos fortes e fracos da escola. É um momento em que a comunidade escolar reflete seus problemas (GESTOR ESCOLAR).

Apesar de otimista com a abrangência do planejamento escolar na perspectiva do PDE- Escola, a gestor também apontou dificuldades encontradas para motivar a comunidade escolar para participar do planejamento como também para coordenar as ações previstas:

O Projeto do PDE- Escola é realizado em diversas etapas, já na primeira delas, a constituição do comitê dos trabalhos, que houve muita resistência das pessoas para participar, ficando com apenas sete membros, dois gestores, três professores, dois componentes do Conselho escolar. Outro fator que dificultou a construção foi o tempo em comum destas pessoas para estudos e deliberações do projeto (GESTOR ESCOLAR).

Para os atores escolares em tela, talvez tenha havido dificuldades de implementar o planejamento da escola em função não ter percebido o planejamento como

Um instrumental desenvolvido para o alcance de objetivos desejados num plano de futuro, de forma mais eficiente, eficaz e efetiva, concentrando esforços e recursos para 
obtenção de melhores resultados, e assim, repensar as suas ações escolares vislumbrando um novo planejar para a instituição.

Seguindo a perspectiva de implantação do PDE- Escola naquela unidade de ensino, conforme informações do gestor escolar, após a capacitação dada na sede da secretaria do município formou-se o grupo que realizaria a construção da proposta de PDE- Escola, através de portaria da secretaria municipal de educação. Entretanto, já nas primeiras reuniões surgiram algumas dificuldades, o entendimento de termos e conteúdos técnicos do projeto que necessitava ser mais bem explicitado para o grupo entender e seguir adiante. Houve a necessidade de intervenção do pessoal da Secretaria de Educação do Município, sendo ofertada uma capacitação na metodologia para os componentes do grupo de trabalho da unidade escolar.

$\mathrm{Na}$ opinião de uma das educadoras as dificuldades eram de ordem cultural, havia pouca prática de planejamento coletivo na escola, e o projeto proposto foi formatado por técnicos do FNDE, com linguagem estritamente técnica, o que ocasionou dúvidas.

A experiência de pensar a escola de forma coletiva, seus problemas e desafios foi provocativa e ao mesmo tempo difícil. Havia uma linguagem técnica que provocavam dúvidas, era preciso estudar, além de haver membros do grupo que pouco refletia ou se envolvia, após a capacitação melhorou a nossa visão das coisas, (EDUCADORA A).

Outra educadora também se manifestou sobre o significado do programa para a escola, tendo emitido a seguinte opinião:

Não conheço muito sobre este programa, já ouvi falar que foi aplicado para escolas que apresentam baixo IDEB. A importância deve estar aí, já que a escola está com índices elevados de reprovação e evasão. Com este projeto deve haver alguma ajuda financeira para a escola pensar estratégias de elevar estes índices e também a qualidade do ensino (EDUCADORA C).

Notadamente havia uma necessidade de intervir na realidade daquela unidade de ensino na busca de melhoria da qualidade dos serviços educacionais prestados a comunidade, além de estar claro que o planejamento é um processo de conhecimento da realidade tendo em vista a sua análise e busca de soluções de problemas. 
Mas, além desta questão técnica outras dificuldades foram manifestadas no planejamento e execução do PDE- Escola, conforme apontadas no Gráfico 1.

Gráfico 1 - Intensidade das dificuldades apontadas pelos entrevistados para o desenvolvimento do PDE- Escola

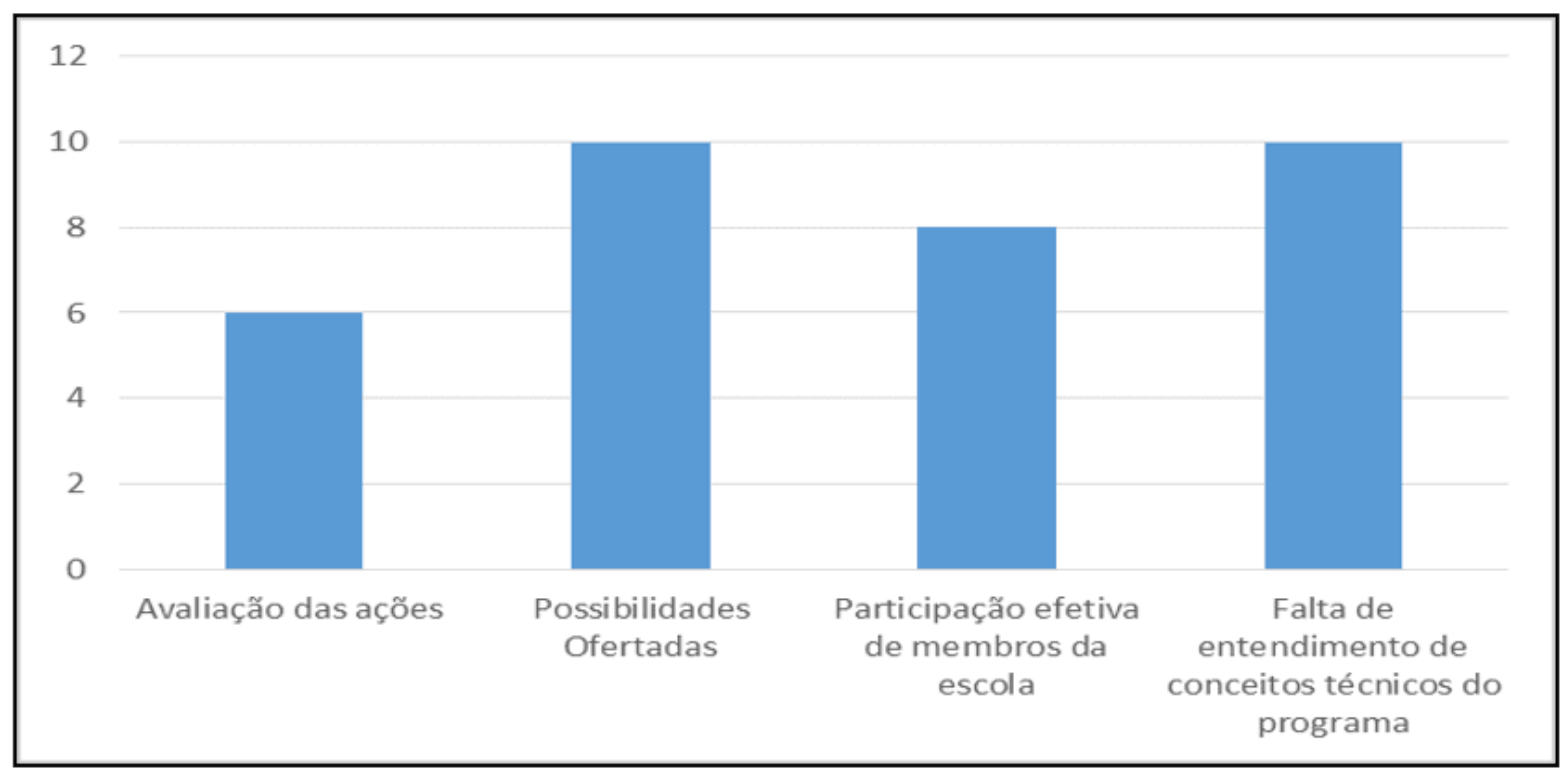

Fonte: Elaborado pelo autor (2018).

Faz se mister observar que pela intensidade de alguns fatores apontados na pesquisa e descritos no gráfico, como por exemplo, a falta de entendimento de conceitos técnicos do programa (90\%) dos integrantes do grupo de trabalho, como também as possibilidades de ações disponibilizadas pelas planilhas eletrônicas do programa que na maioria das vezes não atendiam as necessidades detectadas no diagnóstico realizado, aliadas a não efetiva participação dos atores escolares e a falta de avaliação do trabalho que estava sendo realizado, talvez tenham sido fatores relevantes para a concretização do programa conforme fora idealizado pelos órgãos de comando superior (Fundo Nacional de Desenvolvimento da Educação e Secretarias Estadual e Municipal de Educação), explicitando que a escola, enquanto organização, só terá sucesso se conseguir eficiência, eficácia, efetividade e equidade o que implica planejamento, organização, liderança forte e ações controladas, apontando para a necessidade de uma mudança no modelo de funcionamento das escolas. Assim as escolas precisam planejar, assumir um compromisso diante, daqueles a quem servem 
e da sociedade, ter uma identidade, autonomia, bem como definir metas, estratégias e planos de ação que tragam resultados verificáveis (BRASIL, 2006).

Além dos aspectos de organização interna o desenvolvimento do projeto em termos de entendimento dos aspectos do programa e participação dos atores escolares, outro aspecto relevante foi revelado na pesquisa, os recursos financeiros disponibilizados para a escola. Embora estes sejam fundamentais para a realização de ações que a escola planejou para melhoria de seus serviços, é preciso que estes sejam vistos com cautela, haja vista não serem permanentes, nem mesmos suficientes para atender as necessidades da escola.

Por outro lado, ficou constatado que a busca pela qualidade nos parâmetros do PDEEscola se pauta em dados superficiais de qualidade, baseando-se na verificação mecânica de números ao analisar índices através de resultados estatísticos, desconsiderando a realidade do aluno e do professor, os determinantes sociais e o contexto da própria escola onde tudo se dimensiona e acontece.

Os depoimentos coletados do PDE- Escola não apresentaram uma expressiva contribuição para a qualidade social do ensino da EMEF Oviedo Teixeira, em função de outros fatores estarem envolvidos, passando o programa a ser visto apenas como estratégia para garantir os números exigidos para o IDEB. Esta perspectiva está revelada na fala seguinte:

O PDE- Escola pode ter contribuído em parte, porque este resultado não foi avaliado dentro da escola. Este projeto foi desenvolvido em 2009, e os indicadores saíram em 2011. Assim, pode ter contribuído, mas o mérito não é somente do programa, mas muito dos professores que procuraram mudar tal realidade, a escola tem procurado melhorar estes índices, buscando estratégias tendo em vista a realidade em que estamos localizados (DOCENTE A).

Mas, apesar de ver o programa PDE- Escola como estratégia de alcançar índices, houve também o reconhecimento que o PDE- Escola propiciou alguns momentos de reflexões sobre o fazer coletivo da escola, mobilizando pais, alunos, professores e gestores. Um dos pontos positivos apontados pelos docentes foram os cursos de capacitação ofertados para alguns componentes curriculares como matemática e 
português. Tais cursos foram ofertados a partir dos índices de baixos rendimentos apresentados nestas áreas.

No gráfico 2 demonstra-se a opinião dos entrevistados sobre a importância do PDEEscola para o desenvolvimento das atividades na unidade de ensino.

Gráfico 2 - Opinião Dos Entrevistados Sobre a Importância do PDE- Escola para a unidade de ensino

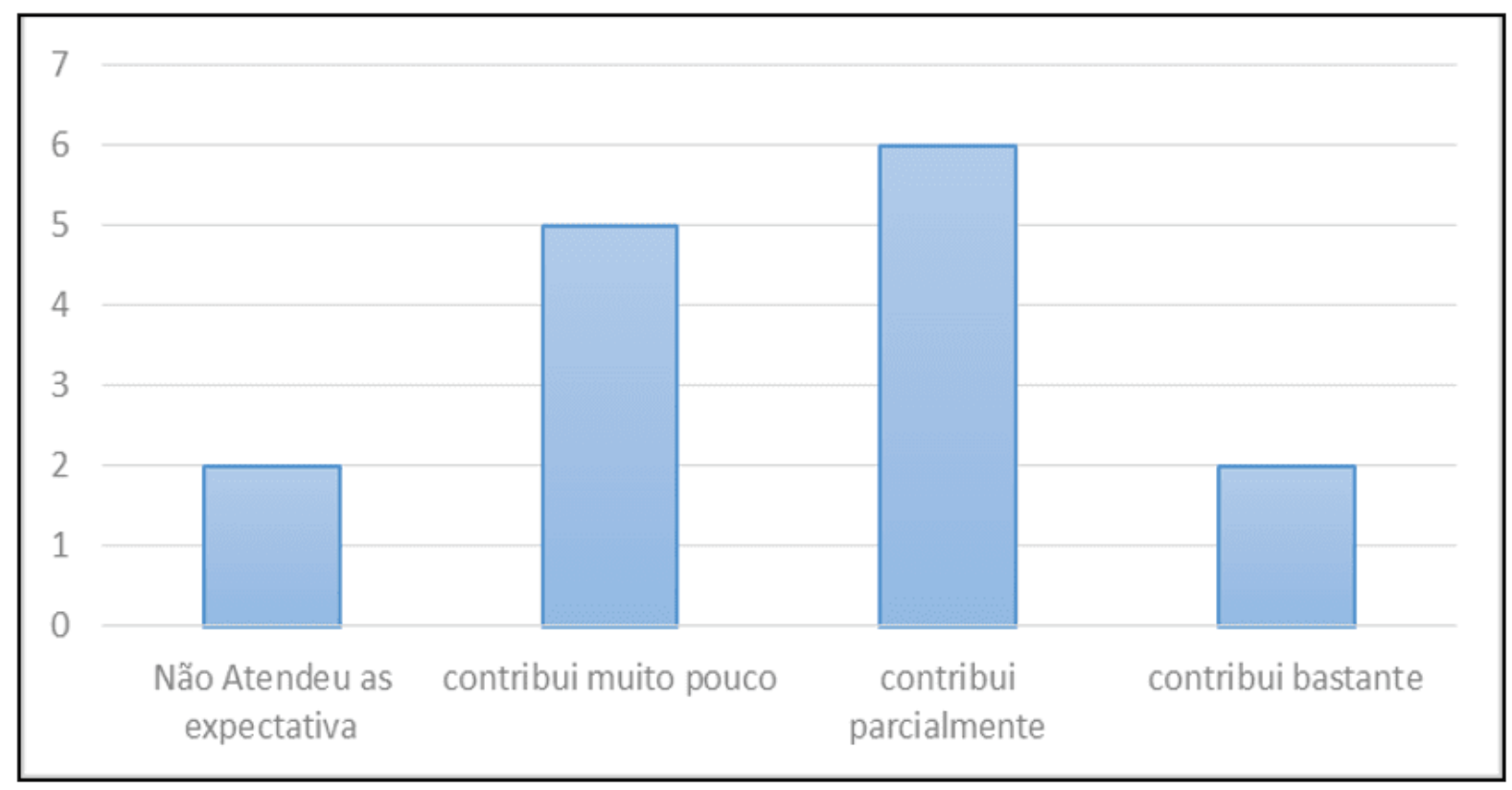

Fonte: Elaborado pelo autor (2018).

Observa-se na leitura do gráfico que a grande maioria dos entrevistados apontaram para uma contribuição parcial do PDE- Escola na o desenvolvimento de trabalhos e atividades escolares que contribuíssem para o real desenvolvimento da escola. Notadamente houve conflito de interesses entre o que se pensou em fazer para a escola e as possibilidades dadas pelas planilhas eletrônicas do programa para a aquisição de materiais didáticos e serviços, assim sendo, a maioria dos recursos adquiridos não foram utilizados pelos professores.

Por outro lado, o programa do PDE- Escola nem se quer foi alinhado as metas e objetivos do Projeto Político Pedagógico da Escola. O PDE- Escola faz uma análise da escola e subsidia com recursos financeiros, colocando-se como uma metodologia 
que busca a melhoria da qualidade do ensino. Entretanto, este não substitui o Projeto Político Pedagógico (PPP), mas sim vem somar suas ações de cunho estratégico a ele.

Neste sentido, indagou-se sobre a interface entre ambos, ficando demonstrado que nem todos os docentes conhecem o projeto político pedagógico da escola, ficando difícil fazer a relação entre o PDE- Escola e o PPP, muito menos vincular as ações de um para o outro, conforme relata uma educadora:

O nosso PPP já começou a discutir, mas ainda não foi finalizado. Já se cuidou da parte de definição teórica, agora iremos analisar as atividades que forma realizadas para traçar novas metas e estratégias. Imagino que não houve diálogo entre estes projetos, até porque não tínhamos o PPP pronto. $\mathrm{Na}$ educação é assim, as coisas acontecem estanques (EDUCADORA D)

Percebe-se que a unidade de ensino nem se quer tinha uma proposta pedagógica formalizada, discutida e escrita à época, e repentinamente teve que fazer adesão a um programa enviado pelo Ministério da Educação/FNDE para efetivar na sua realidade, sem se quer terem seu eixo norteador ainda definido que é o Projeto Político Pedagógico.

Apesar de ser um programa de gestão da escola, não considerou aspectos relevantes como as suas reais necessidades que foram detectadas no próprio diagnóstico, enveredando pelos caminhos disponibilizados nas planilhas do programa e assim fazendo a aquisição de materiais didáticos, tais como: equipamento de rádio escolar, mapas, globo, TV, DVD, filmes, jogos, computador.

Perguntou-se como estaria sendo utilizados tais materiais. A maioria das respostas dadas pelos professores revelou que estes materiais são pouco utilizados ou estão disponíveis aos docentes como deveriam, conforme a Gráfico 3. 
Gráfico 3 - Níveis de Utilização dos Recursos Didáticos Adquiridos no PDE- Escola

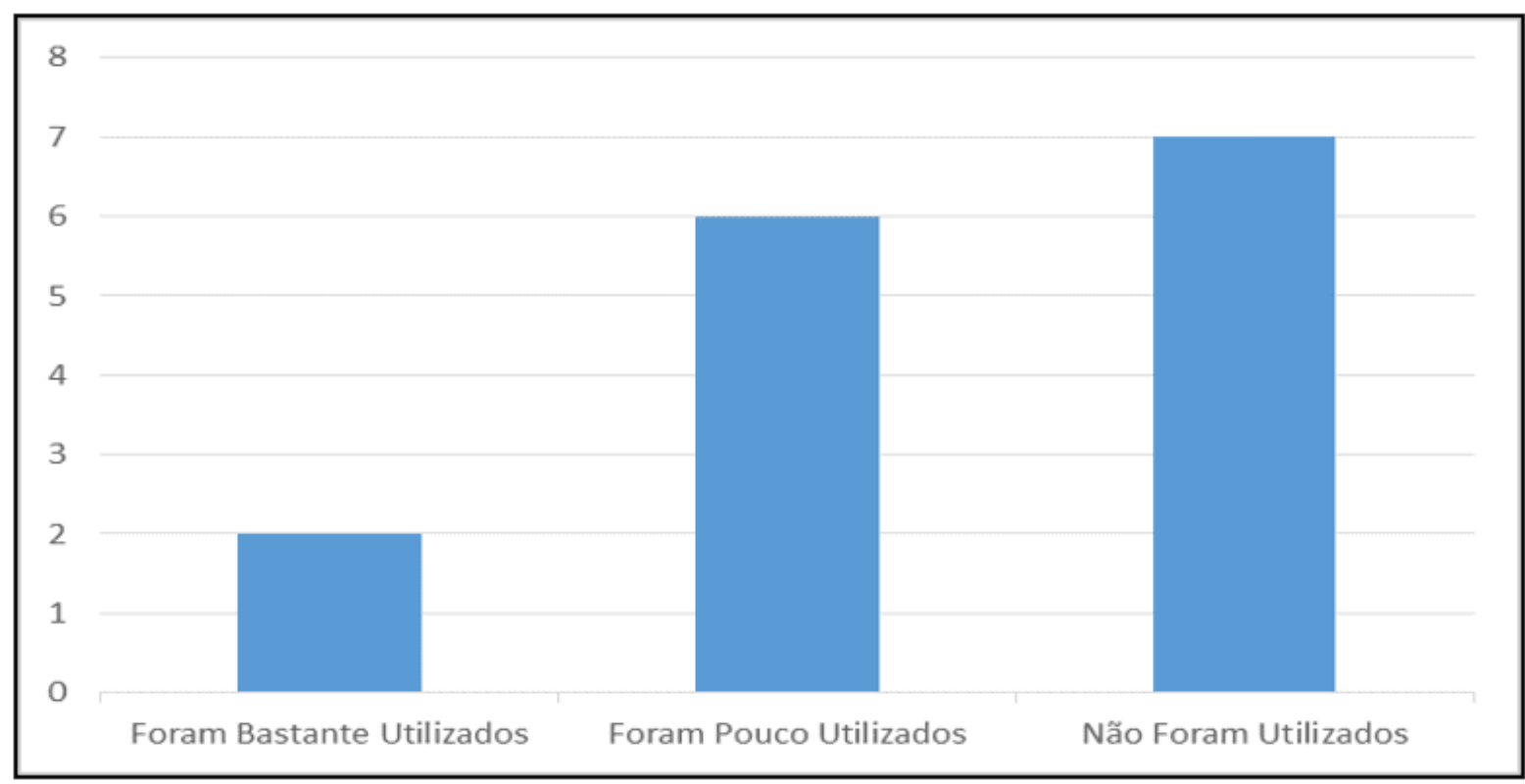

Fonte: Elaborado pelo autor (2018).

Notadamente foram adquiridos os recursos em conformidade com o que a equipe pensou no projeto de PDE- Escola, mas, apesar de estarem disponíveis não estão sendo usados pelos docentes em suas atividades cotidianas. Esta proposição também ficou confirmada na fala de uma educadora.

Os recursos didáticos são importantes, mas aqui pouco se utiliza. Todos têm conhecimento de sua existência na escola, mas falta interesse por parte dos professores, a maioria utiliza o método giz e saliva, não quer ter mais trabalho, seria interessante que se incentivasse o seu uso. Mas também muito recursos ficam guardados e distantes da sala de aula (EDUCADOR C).

Por outro lado, a Gestora Escolar ao ser indagada sobre a aquisição dos recursos didáticos através do PDE- Escola e se estes tiveram importância para o desenvolvimento de atividades pedagógicas, ela respondeu: "estes materiais foram importantes para o desenvolvimento pedagógico da escola, os professores utilizam no cotidiano da sala de aula e já demonstram melhoria nos resultados (GESTORA ESCOLAR). 
Confrontando os depoimentos apresentados percebe-se que há controvérsias a respeito da utilização dos recursos didáticos adquiridos no PDE- Escola, embora eles estejam disponíveis na unidade de ensino. Entretanto, é preciso alertar que os usos de recursos didáticos serão viáveis e significativos na prática pedagógica quando ele se constituir em um elemento de apoio na construção do conhecimento, fornecendo informação e despertando interesse do aluno, motivando a pesquisa e o estudo, propiciando vivências de aprendizagem. A escola precisa aprender este caminho.

\subsection{PLANEJAMENTO ESTRATÉGICO GOVERNAMENTAL DISSEMINADO NA LITERATURA VERSUS METODOLOGIA DO PDE- ESCOLA}

Em termo de estrutura pode-se observar que o programa do PDE- Escola trilha a mesma trajetória metodológica apontada por Dagnino (2009) no planejamento estratégico governamental, apenas com o diferencial de apresentar planilhas eletrônicas, conforme a comparação apresentada no Quadro 3.

Quadro 3 - Comparativo das características metodológicas do Planejamento Estratégico Governamental e PDE- Escola

\begin{tabular}{|c|c|}
\hline $\begin{array}{l}\text { Planejamento } \\
\text { Governamental }\end{array}$ & PDE- Escola \\
\hline $\begin{array}{l}\text { - Ferramenta de gestão; } \\
\text { - Coordenação do projeto; } \\
\text { - Diagnóstico da instituição; } \\
\text { - Definição da identidade } \\
\text { organizacional: missão, visão e } \\
\text { valores; } \\
\text { - Objetivos estratégicos; } \\
\text { - Metas, estratégias } \\
\text { indicadores; } \\
\text { - Plano de ação; }\end{array}$ & $\begin{array}{l}\text { - } \text { Ferramenta de gestão; } \\
\text { - Grupo de sistematização } \\
\text { - } \text { Análise situacional } \\
\text { (diagnóstico/avaliação); } \\
\text { - Planilhas eletrônicas do } \\
\text { programa; } \\
\text { - Definição visão estratégica: } \\
\text { missão, visão de futuro e valores; } \\
\text { - Objetivos estratégicos; }\end{array}$ \\
\hline
\end{tabular}


- Execução, acompanhamento e avaliação.
- Plano de suporte estratégicos: estratégias, metas e planos de ação;

- Execução, monitoramento e avaliação

Fonte: elaborado pelo autor/2018.

Observa-se que em termos metodológicos as matrizes teóricas do planejamento estratégico governamental descrito por Dagnino (2009) e a do PDE- Escola são semelhantes diferenciando-se apenas em função da planilha eletrônica apresentada na plataforma do PDE- Escola que em seu processamento direciona os problemas detectados no diagnóstico realizado na escola e direciona, na maioria das vezes, para soluções que atendem muito mais aos objetivos econômicos do programa do que as necessidades da escola.

\subsection{DIFICULDADES LIMITES, DESAFIOS E ASPECTOS POSITIVOS OBSERVADOS PELOS ENTREVISTADOS NO DESENVOLVIMENTO DO PROJETO}

Dentre os pontos relacionados ao PDE- Escola da EMEF Oviedo Teixeira, pode se destacar: a mobilização da comunidade escolar para discutir os problemas da escola, embora não houve a adesão de parte dos professores; a chegada de verbas, que apesar de ser insuficiente, precisa ser bem administrada, através de um bom planejamento; a falta de fiscalização para verificar o desenvolvimento do plano e sua avaliação. Mas, positivamente é o fato que a escola começou a pensar coletivamente e a cada dia, novas adesões de professores estão acontecendo para os projetos, os resultados vem melhorando gradativamente, ano a ano, graças a ações planejadas, tendo sido o PDE- Escola seu pontapé inicial.

Entretanto, percebe-se que as políticas educacionais instituídas pelo governo nas escolas não têm promovido a descentralização, mas um processo de 
desconcentração de tarefas, onde a participação da comunidade significa que o controle e a fiscalização sobre a escola para que esta tenha ótimos resultados e que a autonomia se configura no ato de implantação de projetos para a escola pela comunidade. Dessa forma, delineia-se uma política na qual o papel do Estado é o de avaliador e controlador das políticas educacionais, a sociedade civil o "cliente" da escola, e assim, deve mantê-la.

Neste contexto, os espaços existentes na escola não foram contemplados com as ações, pois não foi dada a devida autonomia para a escola optar por aquilo que necessita no seu aspecto de estrutura física. Nos moldes do PDE- Escola, existem planilhas dos produtos que podem ser adquiridos, não ficando a cargo da comunidade a escolha dos objetos e tecnologias que esta necessita construir seu fazer pedagógico.

Portanto, ficou evidenciado que o PDE- Escola foi uma proposta para promover a qualidade do ensino, como também o aperfeiçoamento da gestão da escola pública. Entretanto, de acordo com a pesquisa realizada, o PDE- Escola traz em seu bojo uma tentativa de implementação de gestão estratégica, já que a sua elaboração parte do diagnóstico da escola, passando por uma análise institucional e culminando com um planejamento (Plano de Ação), sendo todo o processo realizado de forma participativa, envolvendo a comunidade escolar. No entanto, este não contempla as necessidades essenciais da escola, haja vista procurar atender as prioridades demandadas e instituídas pela reforma do Estado brasileiro dos anos de 1990. A orientação dada para a implementação do PDE- Escola é que tudo depende do envolvimento dos atores que trabalham na escola, onde terão suas funções redimensionadas passando a serem líderes, gerentes de metas, gestores de ações.

\section{CONSIDERAÇÕES FINAIS}

O desenvolvimento do presente estudo possibilitou uma análise do Projeto de Desenvolvimento da Escola (PDE- Escola) numa unidade de ensino da rede pública do município de Aracaju, capital do Estado de Sergipe, que utiliza a ferramenta de planejamento estratégico como forma e reorganização da gestão e serviços ofertados. 
$\mathrm{Na}$ pesquisa coloca-se a questão central: como se configura o Projeto de Desenvolvimento da Escola (PDE- Escola) na Escola de Ensino Fundamental Oviêdo Teixeira? Quais os problemas e desafios encontrados pelos atores sociais na prática deste planejamento estratégico? A partir daí delineou-se objetivos com os quais buscou-se explicitar as questões propostas.

A unidade de ensino que fora objeto de análise participou de uma ação do Ministério da Educação através do Fundo Nacional de Desenvolvimento da Educação (FNDE), visando implementar uma gestão estratégica na escola através do programa PDEEscola.

O programa do PDE- Escola metodologicamente trabalha as diversas etapas do planejamento estratégico: diagnóstico da realidade, análise situacional e de resultados e construção de um plano de ação para trabalhar os problemas detectados nesta trajetória.

Entretanto, apesar de realizar as etapas do planejamento estratégico, o programa do PDE- Escola nos moldes definidos pelo órgão fomentador estava "engessado" por planilhas eletrônicas que eram lançados os dados levantados e discutidos pelo coletivo da escola e este direcionava para as ações e prioridades que deveriam ser realizadas, sendo na maioria das vezes, conflitantes com os problemas e necessidades reais da escola.

Aliado a problemática das ações e recursos pré-direcionados através das planilhas, o programa ainda encontrou resistência por parte de alguns membros da escola em participar ativamente das discussões, estudos e construção do plano de ação, tendo uma adesão por parte dos atores escolares de forma obrigatória, mas não por força de acreditar no trabalho que estaria sendo realizado.

Diante deste quadro, o programa foi desenvolvido de forma precária e indesejada, tanto pela estrutura efetivada (falta de esclarecimentos e treinamento do pessoal para desenvolvimento do projeto) como pela motivação dos membros da equipe para a participação ativa e reflexiva que tal processo requer, daí, seus resultados não 
lograram o êxito pretendido para a referida unidade de ensino, o qual seria a melhoria dos resultados escolares que foram expressos através do índices educacionais, melhorando também a gestão dos serviços oferecidos pela escola e a democratização das relações estabelecidas neste ambiente.

O planejamento estratégico é uma ferramenta de gestão que conforme nos diz Ossorio (2002), permite organizar a complexidade das relações na sociedade e nas organizações; deve contribuir para a criatividade, ser um sistema eficaz de tomada de decisão de modo consciente e reflexivo, resultando na construção intencional das ações. Essa compreensão não foi entendida, nem pelos órgãos de comando, que com instrumentos como a planilha, direcionaram as ações e recursos, e também pela falta de estímulo e treinamento da equipe local; como também pelos membros da coletividade da escola, que em sua maioria se opuseram a participação, tendo sido o projeto efetivado por uma minoria que estavam sendo obrigados a realiza-los pela força do cargo que ocupavam (gestores) ou pela amizade a estes, e nunca por abraçarem a causa tendo em vista o planejamento estratégico da escola.

Considerando que o planejamento estratégico é uma ferramenta de gestão que possibilita diagnosticar e refletir todos os aspectos institucionais, bem como traçar planos de ação e avaliação, possibilitando melhoria dos resultados das instituições, tanto pública quanto privada, e ainda, que a experiência desenvolvida na unidade de ensino, apesar de não ter logrado grandes êxitos, mas trouxe como uma das contribuições a habitualidade de planejar coletivamente a partir dos problemas da escola, sugere-se que haja a continuidade desta metodologia de gestão, entretanto, com algumas particularidades, tanto para os órgãos de comando (MEC/FNDE e Secretarias Estadual e Municipal de Educação), como para os gestores e comunidade escolar:

- Realização de cursos de formação continuada para trabalhar com a metodologia do PDE- escola para todos os representantes da comunidade escolar, mais especificamente, gestores, professores e membros do conselho escolar, visando sensibilizá-los; 
- Desvinculação do planejamento às planilhas eletrônicas adotadas no programa, evitando assim o direcionamento das ações para atividades alheias ou pouco significativas para a resolução dos problemas detectados;

- Avaliação, ex ante e ex post, do projeto construído pela unidade de ensino pelas respectivas secretarias de educação, se necessário intervir, buscando discutir ações e estratégias pensadas visando melhorá-las e adequá-las;

- Liberação de verbas para a execução e desenvolvimento das atividades planificadas, com apoio logístico, monitoramento e avaliação de cada uma;

- Implementar a gestão estratégica de forma efetiva e permanente, não apenas como um programa casuístico.

As sugestões dadas irão corrigir algumas falhas apresentadas na primeira versão, melhorar o nível de credibilidade dos atores escolares e, consequentemente, sua participação nas versões posteriores, assim contribuindo para o aperfeiçoamento dos serviços e seus resultados.

A presente pesquisa não é estanque, este caso de estudo é apenas uma pequena amostragem da trajetória do planejamento estratégico em uma instituição pública, seus problemas e desafios, como também as experiências e contribuições para que os gestores públicos e sociedade. Assim sendo, necessita de continuidade, talvez em outros órgãos públicos e até mesmo por outros pesquisadores, mas que possa contribuir para cada vez mais para o aprimoramento e gestão dos bens e serviços públicos.

Levando-se em consideração que o planejamento estratégico é uma ferramenta de gestão bastante utilizada pelas instituições visando melhorar os serviços e que, apesar de ter sido aplicada na unidade de ensino e não ter surtido os efeitos desejados mas trouxe luzes ao planejamento escolar e as formas de relacionamento, e ainda, que poderá contribuir significativamente para a gestão dos recursos e das pessoas, sugere-se que seja realizado um projeto de intervenção na unidade de ensino, através do diálogo entre os atores escolares e o pesquisador, visando assim superar as 
dificuldades encontradas anteriormente na sua primeira versão (2008) e assim lograr bons resultados para a qualidade dos serviços da escola que tanto se almeja.

A pesquisa objetivou de forma geral analisar a prática de Planejamento Estratégico na Escola Municipal de Ensino Fundamental "Oviedo Teixeira", uma instituição de ensino situada no município de Aracaju, capital do Estado de Sergipe. Pretendeu-se com o estudo descrever o modelo de planejamento estratégico à Luz do PDE- Escola desenvolvido na unidade de ensino, como também, relacioná-lo com o modelo de planejamento estratégico governamental difundido nas academias através de constructos teóricos. E ainda, refletir a implementação do PDE- Escola enquanto prática de Planejamento Estratégico.

Para encontrar as respostas às questões da pesquisa fez se necessário, inicialmente, uma incursão teórica em escritos de autores que versaram sobre os conceitos fundamentais de o que é planejamento, planejamento educacional e planejamento estratégico.

Após esse entendimento foi definida a metodologia da pesquisa, Estudo de caso, e então, elaborou-se um protocolo de estudos tendo em vista organizar as atividades a serem executadas. $O$ desenvolvimento destas atividades tornou-se possível a realização da pesquisa.

A análise do caso se deu através de busca de informações em duas fontes: documentos e entrevista com atores escolares. Na pesquisa documental houve algumas dificuldades em função de que algumas pastas de arquivo documental da escola (projeto elaborado do PDE- escola) não terem sido encontrados num primeiro momento e somente posteriormente foi localizado. Esse problema fez com que empreendesse mais esforços para coleta dos dados em outros documentos (que serviram de base para o documento principal). Mas, durante o período da coleta de dados foi finalmente localizado o projeto de PDE- Escola, dando oportunidade a fazer um cruzamento de dados. 
No que se refere as entrevistas, todas foram realizadas conforme planejado, os atores escolares que foram entrevistados sempre estiveram disponíveis para responder às perguntas elaboradas no questionário, bem como esclarecer algumas dúvidas a respeito do processo desenvolvido durante a efetivação do programa.

O desenvolvimento do programa PDE- Escola nesta instituição de ensino foi realizado na perspectiva de um planejamento estratégico, com todas as etapas bem definidas, desde o diagnóstico, a análise situacional até a definição de um plano de ação. Entretanto, alguns problemas emergiram desde o início: falta de esclarecimento da metodologia para os participantes, vinculação do projeto construído a uma planilha desenvolvida pelo MEC/FNDE e consequentemente desvirtuação de ações pensadas pelos atores escolares, aquisição de materiais didáticos não utilizados pelo corpo docente em suas atividades; falta de estimulação e participação ativa dos atores escolares, falta de credibilidade no programa, principalmente por parte dos docentes, a descontinuidade das ações, a falta de acompanhamento, monitoramento e avaliação por parte dos órgãos de comando e também a necessidade de se tornar uma política de Estado e não somente um projeto. Talvez a soma de tais fatores tenha contribuído para que o programa não tenha alcançado os objetivos pretendidos, embora tenha semeado o despertar do coletivo da escola para a discussão democrática de seus problemas.

Portanto, foi uma experiência válida, necessitando apenas a sua continuidade enquanto política de Estado, pois, a partir de ações estratégicas discutidas, pensadas e planejadas por seus executores (atores locais) com apoio estrutural e financeiro do Estado, possivelmente mudar-se-á a gestão e a qualidade dos serviços públicos prestados a sociedade.

\section{REFERÊNCIAS}

BETHLEM, Agrícola de Souza. Estratégia Empresarial: conceitos, processos e administração estratégica. Editora Atlas S/A, São Paulo, 2009. 
BRASIL, Lei de Diretrizes e Bases da Educação Nacional, Lei 9394/96, São Paulo, Editora do Brasil S/A, 1996.

BRASIL, MEC. Manual Como Elaborar o Plano de Desenvolvimento da Escola, $3^{a}$ edição, Brasília, FUNDESCOLA/FNDE/MEC, 2006.

BRASIL, Plano de Desenvolvimento da Escola Oviêdo Teixeira, Aracaju, 2008.

DAGNINNO, Renato Peixoto. Planejamento Estratégico Governamental. DCA/UFSC/UAB, Florianópolis, 2009.

GANDIN, Danilo. Planejamento como prática educativa. São Paulo: Loyola, 2003. IBGE - INSTITUTO BRASILEIRO DE GEOGRAFIA E ESTAtísticA. Censo Demográfico 2010. Rio de Janeiro: IBGE, 2010a. Disponível em: m: $<$ http//censo2010.ibge.gov.br>.

KWASNICKA, Eunice Lacava. Teoria Geral da Administração: uma síntese. 3. ed. São Paulo: Atlas, 2003.

LIBÂNEO, Jose Carlos. Organização e gestão de escola: teoria e prática. Goiânia: Alternativa, 2013.

MENEGOLLA, Maximiniano; SANT'ANNA, Ilsa Martins. Por que planejar? Como planejar? 13. ed. Petrópolis, RJ: Vozes, 2013.

OLIVEIRA, Djalma de Pinho Rebouças de. Planejamento Estratégico. Conceitos, Metodologias e Praticas. São Paulo, Atlas, 2015.

OSSORIO, Alfredo. Planejamento estratégico. Buenos Aires: INAP, 2002.

ROMÃO, José Eustáquio. Dialética da diferença: o projeto da escola cidadã frente ao projeto pedagógico neoliberal. São Paulo: Cortez/Instituto Paulo Freire, 2013. 
SANTOS, José Roberto Leite dos. Planejamento Estratégico: uma ferramenta acessível à microempresa. In: ENCONTRO NACIONAL DE ENGENHARIA DE PRODUÇÃO, 25. Porto Alegre, 2005. Anais... Porto Alegre: ABEPRO, 2006.

YIN, Robert K. Estudo de Caso: planejamento e métodos. 3. Ed. Porto Alegre: Bookman, 2005.

Enviado: Junho, 2020.

Aprovado: Setembro, 2020. 